\title{
Pemanfaatan Limbah Minyak Jelantah Menjadi Sabun Padat
}

\author{
Anita*1, Fatmawati Muharram²,Dewi Arisanti $^{3}$, Darmaway Rauf ${ }^{4}$, Suardi $^{5}$, \\ Bambang Ariyanto ${ }^{6}$ \\ 1,2,3,4,5 Teknologi Laboratorium Medis, Politeknik Kesehatan Muhammadiyah Makassar \\ ${ }^{6}$ Radiologi Politeknik Kesehatan Muhammadiyah Makassar \\ *E-mail: anitadinar1983@gmail.com
}

\begin{abstract}
Used cooking oil contains compounds that are carcinogenic which pose a risk to human health. Waste cooking oil is also at risk for areas where used cooking oil is disposed, for example into sewers or into the ground. This can contaminate soil and water, thereby endangering humans or the surrounding environment. Therefore, serious action is needed on the use of used cooking oil waste so that it can be utilized optimally as a staple in the soap processing process. Through community service activities which are one of the implementations of the Tridharma of Politeknik Kesehatan Muhammadiyah Makassar Study Program of Medical Laboratory Technology, then education is carried out in the form of counseling to the taklim assembly team at the Al-Hidayah Perumnas Antang Makassar Mosque regarding the use of used cooking oil into solid laundry soap. From this community service activity, it can be concluded that the knowledge of the taklim team at the Al-Hidayah Mosque in Manggala Village, Manggala District, Makassar City regarding the dangers of used cooking oil waste for health and how to process used cooking oil into solid soap.
\end{abstract}

Keywords: Wasting oil,Solid soap

\begin{abstract}
Abstrak
Minyak jelantah memiliki senyawa- senyawa yang bertabiat karsinogenik yang beresiko bagi kesehatan manusia. Limbah minyak jelantah juga beresiko untuk area tempat membuang minyak jelantah misalnya ke selokan ataupun ke tanah. Hal ini bisa mengkontaminasi tanah serta air sehingga membahayakan manusia ataupun lingkungan sekitarnya. Oleh sebab itu dibutuhkan penindakan sungguh-sungguh pada pemakaian limbah minyak jelantah supaya bisa dimanfaatkan maksimal sebagai bahan pokok dalam proses olahan sabun. Melalui aktifitas pengabdian masyarakat yang merupakan salah satu pelaksanan Tridharma Perguruan Tinggi Politeknik Kesehatan Muhammadiyah Makassar Program Studi D3 Teknologi Laboratorium Medis, maka dilakukalah edukasi dalam bentuk penyuluhan kepada tim majelis taklim di Mesjid Al- Hidayah Perumnas Antang Makassar mengenai pemaafaatan minyak jelantah menjadi sabun cuci padat. Dari kegiatan pengabdian pada masyarakat ini dapat disimpulkan bahwa meningkatnya pengetahuan tim majelis taklim Mesjid Al-Hidayah Kelurahan Manggala, Kecamatan Manggala, Kota Makassar mengenai bahaya limbah minyak jelantah bagi kesehatan dan cara pengolahan minyak jelantah menjadi sabun padat.
\end{abstract}

Kata kunci:Minyak jelantah, Sabun Padat

\section{PENDAHULUAN}

Peningkatan pertumbuhan penduduk yang semakin pesat, sebagai akibat dari kenaikan permintaan suatu barang untuk kebutuhan sehari-hari, salah satunya merupakan produk sabun. Berdasarkan data Badan Pusat Statistik (BPS) (2009) tentang data sabun sejak tahun 2004 sebesar 55.832,930 ton yang terus semakin tinggi hingga tahun 2009, yaitu sebesar 101.631,090 ton.

Sabun terdiri dari bahan kombinasi berbentuk senyawa natrium serta asam lemak yang berperan selaku bahan pembersih badan, berupa padat, busa, dengan ataupun tanpa zat tambahan lain dan tidak memunculkan iritasi pada kulit (Badan Standarisasi Nasional,1994). Proses pembuatan sabun bisa dicoba dengan dua metode, ialah proses saponifikasi serta proses netralisasi minyak. Produk sampingan 
dari proses saponifikasi minyak akan diperoleh gliserol, sedangkan pada proses netralisasi tidak terdapat gliserol. Proses saponifikasi terjalin sebab respon antara trigliserida dengan alkali, sebaliknya proses netralisasi terjalin sebab respon asam lemak bebas dengan alkali (Ophardt, 2010).

Minyak makan sisa ataupun yang kerap diketahui selaku minyak jelantah merupakan minyak sisa ataupun minyak limbah yang dapat berasal dari bermacam tipe minyak goreng. Minyak limbah (waste cooking oil) apabila ditinjau dari matriks struktur kimianya apabila dipanaskan bilangan asam serta peroksida yang tercantum di dalamnya akan bertambah, minyak jelantah memiliki senyawasenyawa yang bertabiat karsinogenik, yang terbentuk sepanjang proses penggorengan (Ramdja, 2010).Minyak yang rusak akibat proses oksidasi serta polimerisasi akan menciptakan bahan dengan cita rasa yang tidak enak (Aisyah,2015).

Jutaan rumah tangga (individu maupun industri) yang menciptakan minyak jelantah yang jika diakumulasikan menjadi sangat besar.Terdapat 5.000 sampai 15.000 liter minyak bekas pakai masuk ke badan air dan mengendap di dasar air, terutama di kawasan muara (Kosasih, 2018). Oleh sebab itu sejatinya minyak jelantah menjadi salah satu limbah yang perlu penanganan serius oleh pemerintah Indonesia.

Disamping beresiko bagi kesehatan untuk manusia, limbah minyak jelantah juga beresiko untuk area tempat membuang minyak jelantah misalnya ke selokan ataupun ke tanah. Hal ini bisa mengkontaminasi tanah serta air sehingga membahayakan untuk manusia ataupun lingkungan sekitarnya. Tetapi, sebab minimnya pengetahuan mengrnai bahaya limbah mimyak jelantah bagi lingkungan, masih banyak warga masyarakat ataupun pedagang yang membuang limbah minyak jelantah begitu saja (Kusumaningtyas,2019)

Oleh sebab itu dibutuhkan penindakan sungguh- sungguh pada pemakaian limbah minyak jelantah supaya bisa dimanfaatkan secara maksimal sehingga tidak memunculkan kerugian yang lumayan parah untuk penggunanya baik dari aspek tubuh begitu pula aspek area yang terdapat di dekat kita..

Limbah minyak jelantah yang terdapat pada warga secara universal masih ada terdapat kandungan lemak pada komposisi struktur kimianya. Pada skala sangat kecil di rumah tangga tiap masyarakat, bisa dimanfaatkan selaku bahan pokok dalam proses olahan sabun, perihal ini ialah suatu pemecahan dalam pengelolaan limbah yang efisien serta efektif sehingga warga sanggup memperoleh nilai murah serta pula memperoleh nilai ekologis untuk lingkungan sekitar. Komposisi sabun umumnya terdiri dari senyawa natrium serta pula kalium dengan asam lemak dari minyak hewani ataupun minyak nabati yang bebentuk solid, lunak ataupun liquid, serta berbusa. Sabun dihasilkan oleh proses saponifikasi, ialah hidrolisis lemak jadi asam lemak serta gliserol dalam keadaan basa (Sari, 2019)

Proses pengolahan sabun sesungguhnya tidaklah sesuatu pekerjaan yang susah buat dilaksanakan, sebab tidak hanya gampang dalam melaksanakannya, bayaran produksinya relatif terjangkau dengan bahan- bahan yang terdapat disekitar kita yang sangat mudah ditemui. Oleh sebab itu dalam pembuatan sabun dengan memakai limbah minyak jelantah dipandang selaku kegiatan yang menguntungkan dalam kehidupan di warga, tidak hanya mengirit pengeluaran untuk keluarga kegiatan ini diyakini sanggup menghidarkan warga dari bermacam penyakit dan baik bagi kelestarian lingkungan.

Melalui aktifitas pengabdian masyarakat yang merupakan salah satu pelaksanan Tridharma

Perguruan Tinggi Politeknik Kesehatan Muhammadiyah Makassar Program Studi D3 Teknologi Laboratorium Medis, maka dilakukalah edukasi dalam bentuk penyuluhan kepada tim majelis taklim di Mesjid Al- Hidayah Perumnas Antang Makassar mengenai pemaaafaatan minyak jelantah menjadi sabun padat.

\section{METODE}

Persiapan pelaksanaan meliputi kegiatan sebagai berikut:

1. Persiapan pelaksanan dimulai dengan survei lokasi ke Mesjid Al-Hidayah Perumnas Antang Kecamatan Manggala Kota Makassar.

2. Mengirim surat perizinan kegiatan ke Kantor Kelurahan Manggala, Kecamatan Manggala Kota Makassar. 
3. Mengirim surat perizinan kegiatan ke RW/RT 5 Kelurahan Manggala, Kecamatan Manggala, Kota Makassar.

4. Mengirim surat perizinan kegiatan ke Ketua Pengurus Mesjid Al-Hidayah Kelurahan Manggala, Kecamatan Manggala, Kota Makassar.

5. Persiapan sarana dan prasarana yang dibutuhkan dalam penyuluhan dan simulasi pembuatan sabun padat dari minyak jelantah.

6. Menentukan dan mempersiapkan materi yang akan disampaikan dalam penyuluhan dan simulasi pembuatan sabun padat dari minyak jelantah

Metode yang digunakan dalam kegiatan penyuluhan ini adalah:

1. Penyajian materi penyuluhan dan simulasi pembuatan sabun padat dengan memanfaatkan limbah minyak jelantah.

2. Membuka sesi diskusi antara pemateri dan tim majelis taklim Mesjid Al-Hidayah Kelurahan Manggala, Kecamatan Manggala, Kota Makassar.

3. Memberikan umpan balik sebagai evaluasi untuk mengetahui pemahaman warga tim majelis taklim Mesjid Al-Hidayah Kelurahan Manggala, Kecamatan Manggala, Kota Makassar terhadap materi penyuluhan yang disampaikan pemateri.

\section{HASIL DAN PEMBAHASAN}

Aktifitas Pengabdian kepada masyarakat adalah usaha untuk menyebarluaskan ilmu pengetahuan, teknologi, dan hasil riset kepada masyarakat. Aktifitas tersebut diharapkan mampu memberikan suatu nilai tambah bagi masyarakat, baik dalam kegiatan kebijakan, dan perubahan perilaku kesehatan, khususnya bagi majelis taklim Mesjid Al-Hidayah Kelurahan Manggala, Kecamatan Manggala, Kota Makassar.

Pada aktivitas ini penyuluhan mengenai bahaya minyak jelantah untuk kesehatan. Minyak jelantah ialah minyak sisa gorengan yang biasanya dalam skala rumah tangga, spesialnya untuk ibu- ibu rumah tangga yang sudah digunakan kesekian kalinya. Sama halnya dengan ibu- ibu majelis taklim Mesjid Al- Hidayah Kelurahan Manggala, Kecamatan Manggala, Kota Makassar, masih banyak yang belum mengenali kalau minyak jelantah apabila digunakan terus menerus dalam jangka waktu yang lama akan membahayakan tubuh. Perihal ini disebabkan karena minyak jelantah memiliki asam lemak jenuh yang sangat besar sehingga beresiko untuk tubuh, sebab bisa merangsang bermacam penyakit pemicu kematian, seperti penyakit jantung koroner, stroke, meningkatnya kandungan lipida utamanya kolesterol darah, hipertensi, apalagi bisa merangsang terbentuknya kanker ( Syafiq, 2007).

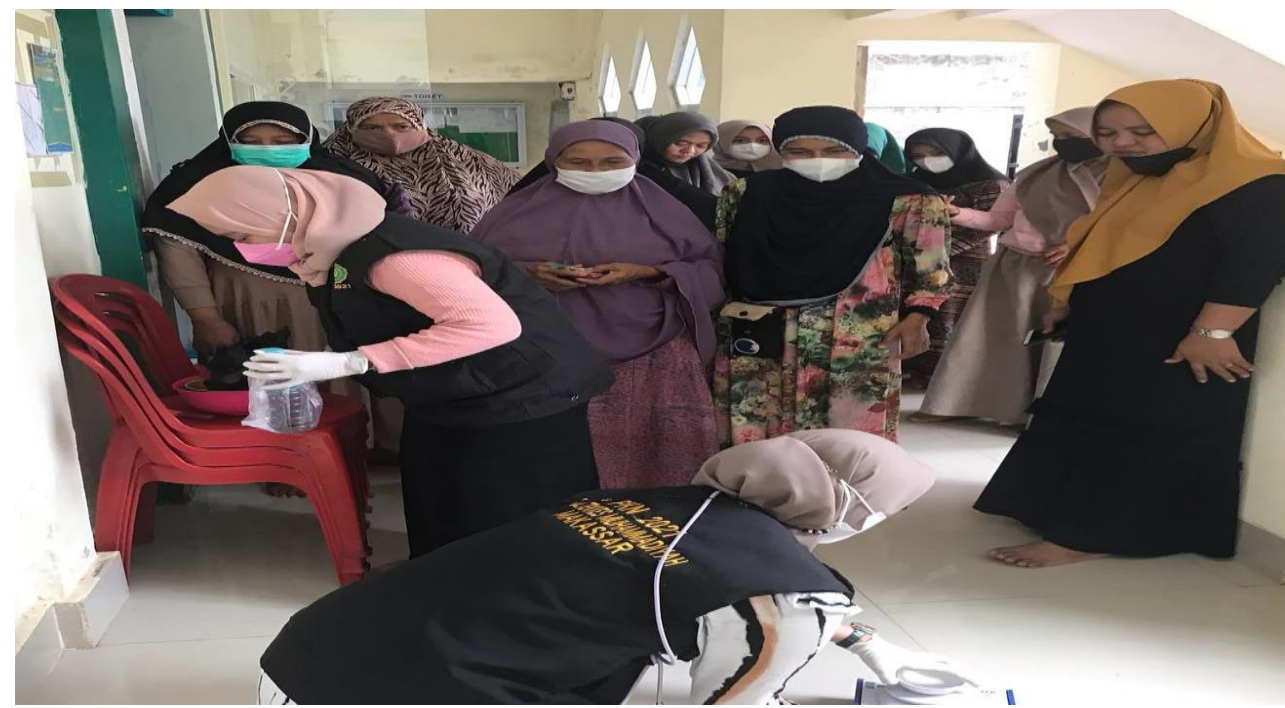

Gambar 1. Penyuluhan dan simulasi pembuatan sabun padat dengan bahan dasar minyak jelantah 
Pada kegiatan penyuluhan ini dilakukan pula simulasi pembuatan sabun padat dari minyak jelantah yang ditambahkan Natrium Hidroksida $(\mathrm{NaOH})$ sebagai bahan pemadat sabun.

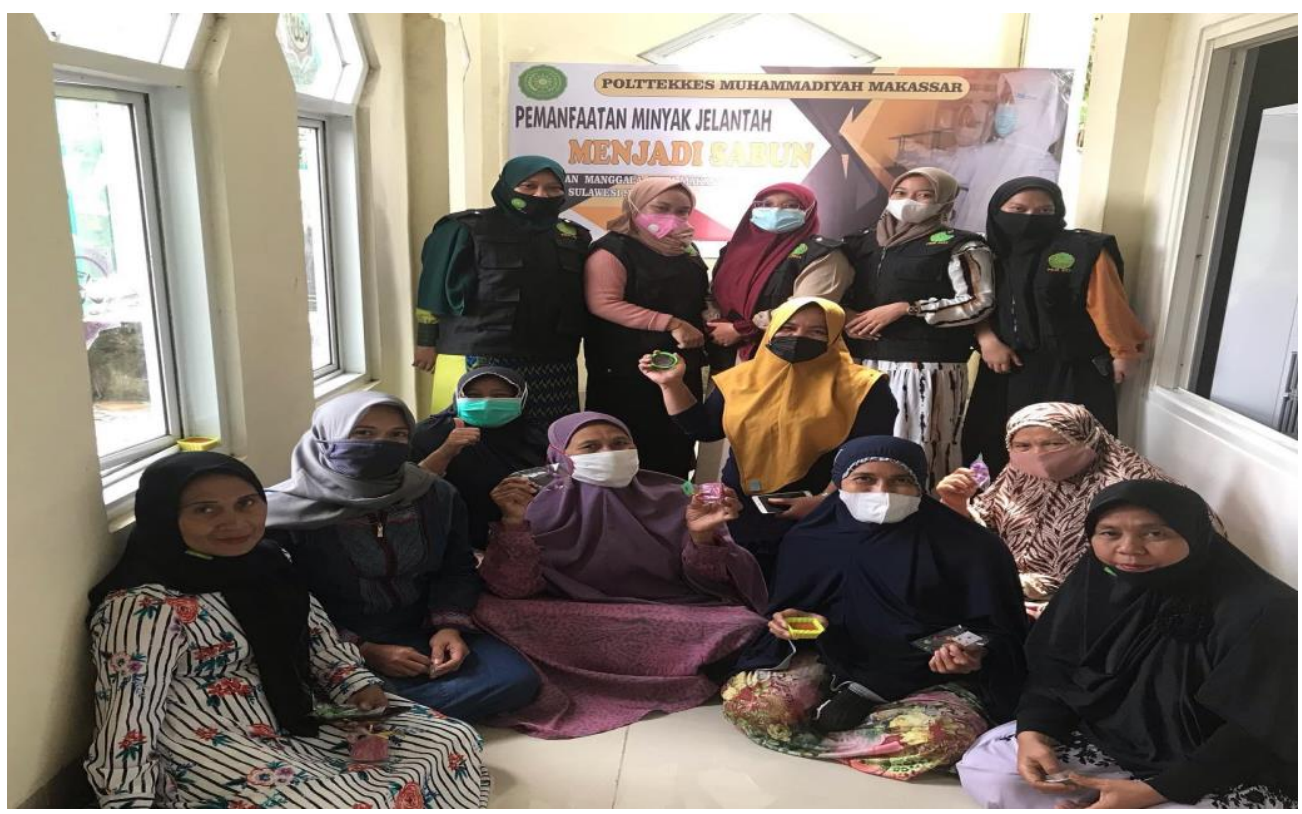

Gambar 2. Peserta simulasi pembuatan sabun padat dari minyak jelantah

Minyak jelantah yang digunakan berkali-kali akan meningkatkan asam lemak bebas, dan hal ini akan mengakibatkan bau yang tengik, bahan gorengan kurang menarik, cita rasa tidak enak, terjadi kerusakan vitamin dan asam lemak esensial Oleh karena itu, minyak jelantah tidak layak untuk dipakai dalam proses penggorengan makanan. Hal ini dikarenakan pemanasan minyak pada waktu digunakan melebihi standar, sedangkan standarisasi pada proses penggorengan normalnya antara $95-120^{\circ} \mathrm{C}$ (Syafiq, 2007).

Usai pendampingan para ibu-ibu taklim di Masjid Al Hidayah, Desa Manggala, Kecamatan Manggala, Kota Makassar, diadakan sesi tanya jawab. Selama sesi ini, terlihat bahwa para wanita taklim di Masjid Al Hidayah tidak mengetahui bahwa akrolein yang terkandung dalam minyak goreng bekas sangat berbahaya jika terserap ke dalam tubuh. Unsur ketidaktahuan di kalangan wanita majelis taklim di Masjid Al Hidayah mungkin karena kurangnya pengetahuan dan kurangnya informasi yang diperoleh, terutama karena mereka tidak pernah diberi penyuluhan tentang bahaya minyak goreng bekas. Ketika minyak dipanaskan sampai suhu tinggi, lemak yang terkandung dalam minyak teroksidasi dan dipecah menjadi gliserol dan asam lemak bebas. Gliserol diubah menjadi akrolein, komponen asap rokok yang mengiritasi mata dan tenggorokan. Selama waktu ini, asam lemak bebas kemudian diubah menjadi lemak trans, yang jika masuk ke dalam tubuh akan disimpan di dinding pembuluh darah.Asap dari pemanasan minyak menunjukkan bahwa nutrisi dalam minyak dan makanan yang dimasak dalam minyak telah berkurang. Oleh karena itu, akrolein sangat berbahaya jika masuk ke dalam tubuh (Almatsier, 2009).

Minyak goreng yang digunakan berkali-kali dapat menghasilkan senyawa radikal bebas yang bersifat racun bagi organ dalam tubuh. Radikal bebas yang berlebihan dalam tubuh dapat merusak sel, termasuk sel otot jantung. Minyak goreng bekas akan mengalami proses oksidasi karena digunakan pada suhu tinggi yang akan merangsang pertumbuhan sel kanker di hati. Pertumbuhan sel-sel hati yang tidak terkendali membuat hati tidak dapat menjalankan fungsinya dengan baik, sehingga menimbulkan berbagai penyakit, termasuk timbulnya kanker. Hal ini didukung oleh Winarno (2002), yang menegaskan bahwa pembentukan senyawa hidroperoksida juga membentuk senyawa radikal bebas yang dapat menyebabkan kanker. 


\section{KESIMPULAN}

Dari kegiatan pengabdian pada masyarakat ini dapat disimpulkan bahwa :

1. Meningkatnya pengetahuan masyarakat tim majelis taklim Mesjid Al-Hidayah Kelurahan Manggala, Kecamatan Manggala, Kota Makassar mengenai bahaya limbah minyak jelantah bagi kesehatan.

2. Meningkatnya pengetahuan masyarakat tim majelis taklim Mesjid Al-Hidayah Kelurahan Manggala, Kecamatan Manggala, Perumnas Antang, Kota Makassar mengenai cara pengolahan minyak jelantah menjadi sabun padat.

\section{UCAPAN TERIMA KASIH}

Penulis mengucapkan terima kasih kepada Direktur Politeknik Kesehatan Muhammadiyah Makassar yang telah memberi dukungan finansial terhadap pengabdian ini.Penulis juga mengucapkan terima kasih kepada Lembaga Penelitian Dan Pengabdian Masyarakat (LPPM) yang telah memberikan peluang melaksanakan kegiatan pengabdian kepada masyarakat majelis taklim Mesjid Al-Hidayah di Kelurahan Manggala, Kecamatan Manggala Perumnas Antang , Kota Makassar.

\section{DAFTAR PUSTAKA}

Badan Pusat Statistik. (2009.) Data Konsumsi, Produksi, Ekspor, dan Impor Sabun Mandi Padat di Indonesia. Jakarta.

Badan Standarisasi Nasional., (1994). Standar Mutu Sabun Mandi. SNI 06-3532-1994. Dewan Standardisasi Nasional. Jakarta.

Ophardt, C. E. Soap. http://elmhurst.edu/- chm/vchembook/554soap.html.

Ramdja, A. F., Febrina, L., \& Krisdianto, D. (2010). Pemurnian minyak jelantah menggunakan ampas tebu sebagai adsorben. Jurnal Teknik Kimia, 17(1).

Aisyah,S., Budiman, H., BR. G, D. F., Aliza, D., Salim, M. N., Balqis, U., \& Armansyah, T. (2015). Efek Pemberian Minyak Jelantah Terhadap Gambaran Histopatologi Hati Tikus Putih (Rattus norvegicus) The effect of Administrating Waste Cooking Oil to Histopathology of Rat ( Rattus norvegicus ) liver. Jurnal Medika Veterinaria, 9(1), 1-4. https://doi.org/10.21157/j.med.vet..v9i1.2989

Kosasih, D. (2018). Minyak Jelantah Berpotensi Cemari Air dan Tanah. Retrieved from Greeners.Co website: https://www.greeners.co/berita/minyak-jelantah-berpotensi-cemari-air-dan-tanah/

Kusumaningtyas, R. D., \& Qudus, N. (2019). Penerapan Teknologi Pengolahan Limbah Minyak Goreng Bekas Menjadi Sabun Cuci Piring Untuk Pengendalian Pencemaran Dan Pemberdayaan Masyarakat. Jurnal Abdimas, 22(2), 201-208.

Sari, P. (2019). PEMBUATAN SABUN MANDI PADAT DARI MINYAK JELANTAH DAN BIJI

KAKAO (Theobroma cacao L.). Cokroaminoto Journal of Chemical Science, 1(1), 10-

Syafiq, A. 2007.Gizi dan KesehatanMasyarakat Edisi Revisi. Jakarta: Raja Grafindo Persada.13.

Almatsier, S. 2009. Prinsip Dasar Ilmu Gizi.Jakarta: PT. Gramedia Pustaka Utama

Winarno, F.G.1995.Kimia Pangan dan Gizi. Jakarta. PT Gramedia Pustaka Jaya Utama 